\title{
Failure to demonstrate Borna disease virus genome in peripheral blood mononuclear cells from psychiatric patients in Korea
}

\author{
Yong Ku Kim ${ }^{1}$, Sang Hyun $\mathrm{Kim}^{2,3}$, So-Hyun Choi ${ }^{4}$, Young-Hoon $\mathrm{Ko}^{1}$, Leen Kim ${ }^{1}$, Min Soo Lee ${ }^{1}$, \\ Kwang Yoon Suh ${ }^{1}$, Dong-Il Kwak ${ }^{1}$, Ki-Joon Song ${ }^{2,3}$, Yong Ju Lee ${ }^{2,3}$, Richard Yanagihara ${ }^{5}$ and Jin-Won Song ${ }^{2,3}$ \\ ${ }^{1}$ Department of Psychiatry and ${ }^{2}$ Department of Microbiology, College of Medicine; ${ }^{3}$ Institute for Viral Diseases, Korea \\ University, 5-Ka, Anam-Dong, Sungbuk-Ku, Seoul 136-705; ${ }^{4}$ YongIn Mental Hospital, 4 Sanghari, Kusungmyun, \\ YongIn-Kun, Kyungki-Do, 449-910, Korea; ${ }^{5}$ Retrovirology Research Laboratory, Pacific Biomedical Research Center, \\ University of Hawaii at Manoa, Honolulu, Hawaii 96816, USA
}

\begin{abstract}
RNA, extracted from peripheral blood mononuclear cells (PBMC) obtained from 81 Korean psychiatric patients (39 with schizophrenia, 33 with bipolar affective disorders and nine with major depression), was analyzed for a 391nucleotide, highly conserved region of the p24 protein-encoding ORF II of Borna disease virus (BDV), using nested reverse transcription-polymerase chain reaction (RT - PCR). BDV genomic RNA was not detected in PBMC from any of the 81 Korean psychiatric patients. These data do not support an etiologic association between BDV infection and neuropsychiatric disorders in humans.
\end{abstract}

Keywords: Borna disease virus; RT-PCR; PBMC; psychiatric disorders

Aberrations in interleukin 2 (IL-2) regulation, including elevated soluble IL-2 receptor in sera of Caucasian and Korean schizophrenic patients (Rapaport et al, 1994) and decreased IL-2 production after mitogen stimulation (Kim et al, 1998), have been regarded as indirect evidence that schizophrenia may have an infectious or autoimmune basis. That viruses (or autoimmunity stimulated by viruses) may be involved in the pathogenesis of major psychiatric disorders, such as schizophrenia, bipolar disorder and major depression (Kirch and Alexander, 1992), is a concept which is gaining increasing support. Recent interest in the potential role of viruses in the pathogenesis of major psychiatric disorders has focused on specific candidate viruses. Originally isolated from horses with behavioral abnormalities and since detected in sheep, cats, ostriches and

Correspondence: J-W Song, Department of Microbiology, College of Medicine, Korea University, 5-Ka, Anam-Dong, Sungbuk-Ku, Seoul 136-705, Korea

This work was presented in part at the 151st annual meeting of American Psychiatric Association in Toronto, Canada, May 30June 4, 1998

Received 10 July 1998; revised 25 August 1998; accepted 26 August 1998 cattle, Borna disease virus (BDV), a member of the Bornaviridae family, possessing a non-segmented, negative-sense, single-stranded RNA genome with five open reading frames (ORF), is one such candidate.

Although BDV has not been definitively shown to cause any human disease, an etiologic association between BDV infection and major psychiatric disorders is tantalizing. Striking clinical similarities have been found between particular animal models of BDV infection and patients with affective disorders or schizophrenia. For example, behavioral disturbances in experimentally infected rats are reminiscent of affective disorders, such as bipolar and monopolar depression, in humans (Lipkin et al, 1995). In particular, the observations that BDVinfected rats have high levels of viral nucleic acid in prefrontal cortex, as well as abnormal mesocortical dopamine activity and abnormal nucleus accumbens dopamine system, suggest the potential for BDV being pathogenetically linked to psychiatric conditions having a dopaminergic substrate, such as schizophrenia and affective disorders (Solbrig et al, 1996a, b).

As determined by the indirect immunofluorescence test (Amsterdam et al, 1985; Rott and Becht, 1995; Bode et al, 1993) and Western blot analysis 
(Fu et al, 1993; Waltrip II et al, 1995), antibodies against BDV have been reported previously in patients with psychiatric disorders. By contrast, genomic analyses of BDV in psychiatric patients have yielded conflicting results. Whereas researchers in Germany and Japan have detected BDV nucleic acid in peripheral blood mononuclear cells (PBMC) of patients with schizophrenia and affective disorders (Bode et al, 1995; Kishi et al, 1995; Sauder et al, 1996; Igata-Yi et al, 1996), other investigators have been unsuccessful in detecting BDV genomic sequences in brain tissue, cerebrospinal fluid or PBMC (Sierra-Honigmann et al, 1995; Richt et al, 1997). Using nested reverse transcription-polymerase chain reaction (RT-PCR), we analyzed RNA extracted from PBMC of Korean patients with schizophrenia, bipolar affective disorders and major depression for a 391-nucleotide, highly conserved region of the p24 protein-encoding ORF II of BDV.

After obtaining informed consent, 81 inpatients (39 with schizophrenia, 33 with bipolar affective disorders and nine with major depression) (Table 1) from Korea University Hospital and Yong-In Mental Hospital, diagnosed according to DSM-IV criteria (American Psychiatric Association 1994), were studied during January to August 1997. Quantitative evaluations were based on the Brief Psychiatric Rating Scale (Overall and Gorham, 1962) for patients with schizophrenia, the Rating Scale for Mania (Young et al, 1978) for patients with bipolar affective disorders, and the Hamilton Rating Scale for Depression (Hamilton, 1960) for patients with major depression. All patients had psychotic or active symptoms at the time of study enrollment (Table 1), and at the time of blood collection, patients were drug-free or being maintained on various neuroleptic or other types of medications. All study participants lived in urban areas and none had contact with horses, sheep or cattle.

Table 1 Descriptive features of study subjects.

\begin{tabular}{lccc}
\hline Diagnosis & Numbers & $\begin{array}{c}\text { Mean age } \\
\text { (years) }\end{array}$ & $\begin{array}{c}\text { Test } \\
\text { score }^{a}\end{array}$ \\
\hline Schizophrenia & 39 & $38.3 \pm 9.2$ & $45.4 \pm 12.3$ \\
$\quad$ Paranoid & 18 & & \\
$\quad$ Undifferentiated & 14 & & \\
Disorganized & 5 & & \\
$\quad$ Catatonic & 2 & $28.5 \pm 7.6$ & $30.4 \pm 8.5$ \\
Bipolar disorder & 33 & & \\
$\quad$ Manic/hypomanic & 31 & & \\
$\quad$ Depressed & 2 & $43.0 \pm 7.1$ & $34.5 \pm 5.3$ \\
Major depression & 9 & &
\end{tabular}

${ }^{\mathrm{a}}$ Quantitative test scores (mean \pm s.d.) were based on the Brief Psychiatric Rating Scale for patients with schizophrenia, the Rating Scale for Mania for patients with bipolar affective disorders, and the Hamilton Rating Scale for Depression for patients with major depression.
BDV RNA was amplified by RT - PCR from PBMC of the psychiatric patients. PBMC separated by Ficoll-hypaque gradient centrifugation from blood samples collected from 81 psychiatric patients. Total RNA was extracted from PBMC using RNA zol (GIBCO/BRL, Gaithersburg, MD, USA). cDNA was initially synthesized for $1 \mathrm{~h}$ at $42^{\circ} \mathrm{C}$ using Superscript II RNase H-Reverse Transcriptase (GIBCO/BRL). RNA extracted from BDV-infected rat brain was used as a positive control. BDV sequences were amplified by nested PCR using the following previously described oligonucleotide primers which afforded amplification of a 391-nucleotide region of the p24-encoding ORF II of BDV (Kishi et al, 1995) : 5' -TGACCCAACCAGTAGACCA-3'+1387; 5'-GTCCCATTCATCCGTTGTC-3' - 1865; 5'-TCAGACCCAGACCAGCGAA-3'+1443; 5' GAAATGCGCG-3' -1834 . Primers for $\beta$-actin were $5^{\prime}$ - TGGAATC CTGTG GCATC CATGAAA - $3^{\prime}$ and 5'-TAAAACGCAGCTCAGTAACAGTC CG-3' (product size, $348 \mathrm{bp}$ ) (Tokunaga et al, 1986). Primers were used at a final concentration of $0.1 \mu \mathrm{M}$ in a $50 \mu \mathrm{L}$ reaction mixture (10 $\mathrm{mM}$ Tris- $\mathrm{HCl}, \mathrm{pH} 8.3$, $50 \mathrm{mM} \mathrm{KCl}, 1.5 \mathrm{mM} \mathrm{MgCl}_{2}, 0.2 \mathrm{mM}$ each dNTP) containing $2.5 \mu \mathrm{L}$ of $\mathrm{CDNA}$ and 2.5 units of AmpliTaq polymerase (Perkin Elmer Co., Norwalk, CT, USA).

Reaction mixtures were cycled 40 times: denaturation for $1 \mathrm{~min}$ at $94^{\circ} \mathrm{C}$, annealing for $1 \mathrm{~min}$ at $50-55^{\circ} \mathrm{C}$, and extension for $2 \min$ at $72^{\circ} \mathrm{C}$ in a DNA thermal cycler (Perkin-Elmer model 480). Amplicons of first round PCR were subjected to 40 cycles of nested PCR using the same cycling conditions. Amplified products were size fractionated by electrophoresis on $1.5 \%$ agarose gels containing ethidium bromide at $0.5 \mu \mathrm{g} / \mathrm{ml}$. PCR products of positive control and $\beta$-actin were purified by Wizard PCR Preps DNA Purification System (Promega, Madison, WI, USA). DNA sequencing was performed in both directions of each PCR product, using the dye termination cycle sequencing ready reaction kit (Applied Biosystems Inc., Foster City, CA, USA) on an automated sequencer (Model 377, Perkin Elmer Co.).

Using nested RT - PCR, successful amplification of BDV-specific RNA and $\beta$-actin mRNA was achieved with BDV-infected rat brain (Figure 1). However, specific viral nucleic acid sequences were not detected in any of the PBMC samples from the 81 psychiatric patients tested.

Previously, Bode et al (1995) reported BDV nucleic acid in four of six $(66.7 \%)$ psychiatric patients, and Sauder et al (1996) found such sequences in 13 (seven patients with schizophrenia, one with affective disorder and five with other psychiatric disorders) of 26 (50\%) neuropsychiatric patients. Moreover, in Japan, BDV-specific RNA was detected in 22 of 60 (37\%) neuropsychiatric patients (Kishi et al, 1995) and in six (five patients with schizophrenia, one with depression) of 55 


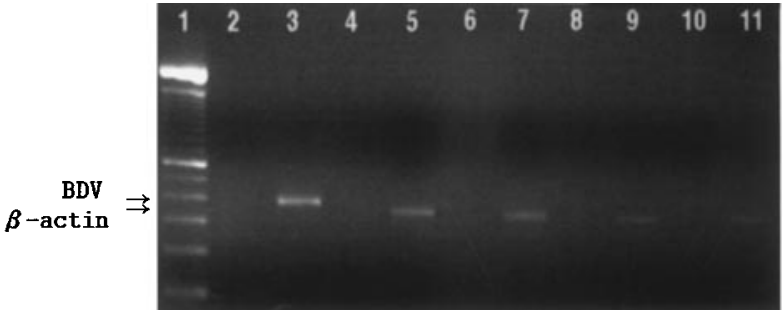

Figure 1 RT-PCR amplification of Borna disease virus (BDV) RNA in PBMC from Korean psychiatric patients. Lane 1: molecular weight marker (100 bp DNA Ladder, GIBCO BRL); lane 2: negative control; lane 3: BDV-infected rat brain cDNA control, showing BDV-specific $391 \mathrm{bp}$ product; PBMC cDNA from patients with schizophrenia (lanes 4 and 5), bipolar mania (lanes 6 and 7), bipolar depression (lanes 8 and 9), and major depression (lanes 10 and 11). As shown, the $348 \mathrm{bp} \beta$-actin gene product was successfully amplified in all samples (lanes 5, 7, 9 and 11).

$(10.9 \%)$ psychiatric patients, compared to none of 36 blood donor controls (Igata-Yi et al, 1996). Finally, in examining the limbic structures of postmortem brain samples from 75 North American and European individuals with various brain disorders for BDV $\mathrm{P}$ gene mRNA by RT-PCR, Salvatore et al (1997) reported the presence of BDV nucleic acids in the brains from nine of 17 patients with schizophrenia and from two of five patients with bipolar disorder. However, BDV p24 genome has also been found in normal human brain

\section{References}

American Psychiatric Association (1994). Diagnostic and Statistical Manual of Mental Disorders, 4th Edition, Washington DC, American Psychiatric Association Press.

Amsterdam JD, Winokur A, Dyson W, Herzog S, Gonzales F, Rott R, Koprowski H (1985). Borna disease virus: a possible etiologic factor in human affective disorders? Arch Gen Psychiatry 42: 10931096.

Bode L, Ferszt R, Czech G (1993). Borna disease virus infection and affective disorders in man. Arch Virol (suppl) 7: 159-167.

Bode L, Zimmerman W, Ferszt R, Steinbach F, Ludwig H (1995). Borna disease virus genome transcribed and expressed in psychiatric patients. Nature Med 1: 232236.

Fu ZF, Amsterdam JD, Kao M, Shankar V, Koprowski H, Dietzschold B (1993). Detection of Borna disease virus-reactive antibodies from patients with affective disorders by western immunoblot technique. J Affect Disord 27: 61-68.

Haga S, Yoshimura M, Motoi Y, Arima K, Aizawa T, Ikuta K, Tashiro M, Ikeda K (1997). Detection of Borna disease virus genome in normal human brain tissue. Brain Res 770: 307-309. tissues (Haga et al, 1997), suggesting that BDV may infect the human brain without leading to neuropsychiatric disease.

Although we used the same oligonucleotide primers as Kishi et al (1995) for amplification of BDV p24, we were unable to demonstrate BDVspecific RNA in PBMC samples from 81 Korean psychiatric patients. Recently, Kubo et al (1997), using the identical primers, also demonstrated no association between BDV infection and psychiatric disorders among Japanese patients. In addition, three other groups have similarly failed to detect BDV-specific RNA in PBMC and/or brain biopsy samples from patients with schizophrenia and affective disorders (Sierra-Honigmann et al, 1995; Lieb et al, 1997; Richt et al, 1997). Neither infectious virus nor BDV-specific RNA was detectable in PBMC of psychiatric patients who exhibited serum antibodies reactive to the p24 and/ or p38 antigens of BDV (Sierra-Honigmann et al, 1995; Richt et al, 1997). This raises concerns about the actual source of the antigenic stimulus in humans, and whether antigenic mimicry is involved.

The precise reasons for these conflicting data are not readily apparent. The potential for laboratory contamination with BDV RNA or cDNA and the exquisite sensitivity of nested RT-PCR may account for the above-mentioned discrepancies. Thus, definitive support for an etiologic association between BDV infection and neuropsychiatric disorders in humans is still lacking.

Hamilton M (1960). A rating scale for depression. J Neurol Neurosurg Psychiatry 23: 56-62.

Igata-Yi R, Kazunari Y, Yoshiki K, Takemoto S, Yamasaki H, Matsuoka M, Miyakawa T (1996). Borna disease virus and consumption of raw horse meat. Nature Med 2: 948-949.

Kim YK, Lee MS, Suh KY (1998). Decreased interleukin2 production in Korean schizophrenic patients. Biol Psychiatry 43: $701-704$

Kirch DG, Alexander RC (1992). Viruses, autoimmunity, and psychiatric disorders. In: American Psychiatric Press Review of Psychiatry, Vol 11. Tasman A, Riba MB (eds). Washington DC, American Psychiatric Press, pp 202-218.

Kishi M, Nakaya T, Nakamura Y, Zhong Q, Ikeda K, Senjo M, Kakinuma M, Kato S, Ikuta K (1995). Demonstration of human Borna disease virus RNA in human peripheral blood mononuclear cells. FEBS Letters 364: 293-297.

Kubo K, Fujiyoshi T, Yokoyama MM, Kamei K, Richt JA, Kitze B, Herzog S, Takigawa M, Sonoda S (1997). Lack of association of Borna disease virus and human T-cell leukemia virus type 1 infections with psychiatric disorders among Japanese patients. Clin Diagn Lab Immunol 4: 189-194. 
Lieb K, Hallensleben W, Czygan M, Stitz L, Staeheli P (1997). No Borna disease virus-specific RNA detected in blood from psychiatric patients in different regions of Germany. Lancet 350: 1002.

Lipkin WI, Schneemann A, Solbrig MV (1995). Borna disease virus: implications for human neuropsychiatric illness. Trend Microbiol 3: 64-68.

Overall JE, Gorham DR (1962). The brief psychiatric rating scale. Psychol Rep 10: 799-812.

Rapaport MH, McAllister CG, Kim YS, Han JH, Pickar D, Nelson DL, Kirch DG, Paul SM (1994). Increased serum soluble interleukin-2 receptors in Caucasian and Korean schizophrenic patients. Biol Psychiatry 35: $767-771$.

Richt JA, Alexander RC, Herzog S, Hooper DC, Kean R, Spitsin S, Bechter K, Schuttler R, Feldmann H, Heiske A, Fu ZF, Dietzschold B, Rott R, Koprowski H (1997). Failure to detect Borna disease virus infection in peripheral blood leukocytes from humans with psychiatric disorders. J NeuroVirol 3: 174-178.

Rott R, Becht H (1995). Natural and experimental Borna disease in animals. Curr Top Microbiol Immunol 190: $17-30$.

Salvatore M, Morzunov S, Schwemmle M, Lipkin WI and Bornavirus study group (1997). Borna disease virus in brains of North American and European people with schizophrenia and bipolar disorder. Lancet 349: 21: 1813-1814.

Sauder C, Muller A, Cubitt B, Mayer J, Steinmetz J, Trabert W, Ziegler B, Wanke K, Mueller-Lantzsch N, de la Torre JC, Grasser FA (1996). Detection of Borna disease virus (BDV) antibodies and BDV RNA in psychiatric patients: evidence for high sequence conservation of human blood-derived BDV RNA. J Virol 70: $7713-7724$.
Sierra-Honigmann AM, Carbone KM, Yolken RH (1995). Polymerase chain reaction (PCR) search for viral nucleic acid sequences in schizophrenia. $\mathrm{Br} J$ Psychiatry 166: 55-60.

Solbrig MV, Koob GF, Fallon JH, Reid S, Lipkin WI (1996a). Prefrontal cortex dysfunction in Borna disease virus (BDV)-infected rats. Biol Psychiatry 40: $629-636$.

Solbrig MV, Koob GF, Joyce JN, Lipkin WI (1996b). A neural substrate of hyperactivity in Borna disease: changes in brain dopamine receptors. Virol 222: $332-$ 338.

Tokunaga K, Taniguchi H, Yoda K, Shimizu M, Sakiyama S (1986). Nucleotide sequence of a fulllength cDNA for mouse cytoskeletal beta-actin mRNA. Nucleic Acids Res 14: 2829.

Waltrip II RW, Buchanan RW, Summerfelt A, Breier A, Carpenter Jr WT, Bryant NL, Rubin SA, Carbone KM (1995). Borna disease virus and schizophrenia. Psychiatry Res 56: 33-44.

Young RC, Biggs JT, Ziegler VE, Meyer DA (1978). A rating scale for mania: reliability, validity and sensitivity. Br J Psychiatry 133: 429-435. 